\title{
$7 \quad$ Wagner, Hearing Loss and the Urban Soundscape of Late Nineteenth-Century Germany
}

JAMES DEAVILLE

On 4 July 1878, the inhabitants of New York City quietly celebrated the festive day, with 'no public exhibitions of fire-works, and no fire-crackers', based on the municipal decision 'to exclude noise and bombast on holiday occasions ... because the interminable din of city life operates as a silent and impalpable force' in citizens' lives. ${ }^{1}$

A decade later, the Victorian periodical All the Year Round - edited by the son of Charles Dickens - issued the following in a diatribe against noise in London:

The dweller in London ... has to put up with many annoyances ... There is none more aggravating, none more harmful than noise. Few realise what noise really means and implies - a disturbance not merely of the ears, but of the brain and nerves, is involved by the continual rattle and roar with which we are surrounded; and physicians tell us that nervous ailments are frequently produced - more frequently rendered doubly severe - by the continued tension thus called into existence. $^{2}$

Within twenty years, the noise of metropolises had become so intolerable that the philosopher and noise-abatement crusader Theodor Lessing was compelled to publish his classic text Noise: A Polemic against the Noises of our Lives, in which he viscerally evokes the soundscape of the modern city, in this case, Berlin:

Hammers thud, machines rumble, the wagons of butchers and the carts of bakers roll past the house before daybreak. Countless bells wail uninterruptedly. Thousands of doors open and close. Thousands of hungry people ... haggle and

1 [unsigned] 1878a, 5. The muted celebration took place in a time of auditory crisis for the city, since a group of 138 physicians had just petitioned the court to alleviate the noise created by the trains of the Metropolitan Elevated Railway Company, which 'disturbs and interrupts all mental processes ... [and] is capable of doing, and undoubtedly will do, great and permanent injury to those who may be compelled to live within reach of its force'. [unsigned] $1878 \mathrm{~b}, 8$. See also Thompson 2004, 145, for a brief discussion of Edison's attempts to measure the railway's noise levels.

2 [unsigned] 1889, 474. 
scream, they scream and argue beside our very ears and fill the streets of the city with their business and their trade ... The streetcar screeches. A train rolls over the iron bridge. Straight through my aching head, straight through our finest thoughts. $^{3}$

It was this noisy, modern urban environment, this acoustic excess that invited contemporary commentators on Wagner to apply their experiences of the metropolitan soundscape to his music, inspired by a burgeoning medical discipline dedicated to studying the ear and its diseases and injuries. In this chapter, I will examine the emergence of the science of otology and its response to the urban sonic environment of the late nineteenth century, and then explore the literature about music and Wagner for evidence of this new 'otic' vocabulary. Along the way, we shall observe how the new-found interest in the act of listening ties in with burgeoning discourses of materiality in the late nineteenth century.

At the outset, it is important to separate the threads that bind together our investigation of Wagner, hearing loss and the urban environment: (1) sober assessments by medical experts inform the fear of Wagner's impact upon hearing; (2) prevalent criticism of the loudness of his music was grounded on the prevailing uncertainty over the thresholds for tolerating auditory volume; (3) as a result of that unease, any kind of change whether social, industrial or musically stylistic - became the lightning rod for anxieties, which found voice in music criticism that latter-day musicologists have all too easily been able to dismiss as hyperbole.

Well before Lessing's description of urban noise pollution, municipal authorities had recognised the disruptive capabilities of urban noise. Already in 1595 the city of London came under an ordinance limiting domestic and industrial sound between the hours of 9 p.m. and 4 a.m. ${ }^{4}$ Regulations of this sort multiplied as the Industrial Revolution of the nineteenth century brought industry and traffic into the city - for example, in 1842 the city council of New Orleans passed a law that restricted the blowing of horns by carriage drivers. ${ }^{5}$ The seeming universality of the remediation of urban noise nuisances through municipal ordinances is indicative of a broader move within industrialised cities to regulate their auditory environment. ${ }^{6}$ Before mid-century the ordinances pertained to human agents in unlawful noise production, in the form of 'any noise,

3 Lessing, cited in Fritzsche 1998, 172-3.

${ }^{4}$ Goldsmith 2012, 45. Noise ordinances that regulate the human production of nocturnal sounds have persisted to the present. Most pre-industrial societies imposed curfews after sunset, however, which would have enforced the noise ordinances.

${ }^{5}$ Young 2011. ${ }^{6}$ Smilor 1979. 
disturbance or improper diversion in the streets.' As the century progressed, however, corporations and municipalities served more frequently as the objects of legal complaints regarding noise, reflecting the increasing levels of urban noise pollution. ${ }^{8}$ Jacques Attali culturally positions the rise of noise ordinances in the modern urban soundscape: 'In the codes that structure noise and its mutations we glimpse a new theoretical practice and reading: establishing relations between the history of people and the dynamics of the economy on the one hand, and the history of the ordering of noise in codes on the other; predicting the evolution of one by the forms of the other; combining economics and aesthetics."

Concurrent with the criminalisation of disturbing the peace through noise was the growing recognition that it was unhealthy: popular and scholarly writers of the late nineteenth century increasingly identified noise as one of the sources of personal harm in the metropolis. For example, in the essay ‘Über den Lärm’ from 1879, Emmy von Dincklage proclaimed that 'no age since the creation of the world has made so much and so egregious noise as ours' ${ }^{10}$ In the same year the noted English psychologist James Sully produced a major study 'Civilisation and Noise', in which he observed: 'persons at all sensitive to noises are exposed to an amount of suffering which may appreciably colour their conscious existence'. ${ }^{11}$ A few years earlier, Army Corps of Engineers road specialist Quincy Adams Gillmore could assert the following: 'The writings of eminent medical practitioners are full of testimony to the pernicious influence of street noise and din upon the health of the population, particularly upon invalids and persons with sensitive

7 The Revised Laws and Ordinances of the City of Troy (Troy, NY: Tuttle, Belcher \& Butler, 1838), 118.

8 The landmark British legal case Sturges v. Bridgman from 1879 decided against the noisemaker defendant, a confectioner's shop, opening the way for other lawsuits against commercial disturbers of the peace. See also Karin Bijsterveld's (2008, 69-71) discussion of hearing loss among boiler boys in the context of late nineteenth-century Amsterdam. A legal encyclopedia from late in the century establishes that 'inconvenience and annoyance occasioned by noise and confusion of passing trains has also been allowed an injury for which compensation has been claimed'. 'Noise and Vibration', The American and English Encyclopedia of Law, ed. John Houston Merrill, 31 vols. (Northport, NY: Edward Thompson Company, 1888), 6:547.

9 Attali 1985, 5.

10 'Kein Zeitalter seit Erschaffung der Welt hat soviel und so ungeheuerlichen Lärm gemacht wie das unsrige.' Dincklage 1879, 413.

11 Sully 1879, 233. Sully studied with Herrmann von Helmholtz in Berlin and authored several studies on the psychology of music, and the interest in apperception that an earlier article 'Physiological Psychology in Germany' from 1876 - had displayed in the first issue of a quasipopulist journal (Mind) has caused Benjamin Steege $(2012,118)$ to remark on the 'urgency' with which the topic of auditory attention was being taken up by the mid-1870s. 
nerves. ${ }^{, 12}$ Furthermore, under the title 'Noise Nuisance', the Cincinnati Lancet and Clinic of 1883 complained that 'to the sick and convalescent, and to "nervous people" - a class rapidly increasing in number with the progress of our civilization - street noise is an intolerable nuisance which, in some cases, may result in positive injury, and is a penalty paid for living in the city'. ${ }^{13}$ And to the extent that insomnia is counted among modern diseases by such an eminent medical authority of the late nineteenth century as British physician Benjamin Ward Richardson, its causes - including the noise of modern life - came under fire: ${ }^{14}$

The development of insomnia is a fatal drawback to the many gains which modern life has brought us ... While insomnia has many causes, it is always kept alive by noise, and in cities like London and Paris noise is always going on day and night. ${ }^{15}$

Such proscriptions against injurious urban noise cut across municipal and national boundaries in the late nineteenth century, in so far as the same clamorous technologies were introduced to cities across Europe and North America: streetcars, factory whistles, steam engines and other factory machinery. ${ }^{16}$ As a result, the evidence from a variety of urban soundscapes and medical practices - where the hazards of technologically produced noise, as well as the otological responses to their effects, achieved their own discourses - elides regional and national differences.

These attributions of injury to sounds, whether physiological or psychological, may have originated in response to what seemed to be the increasingly loud and complex soundscape of the modern metropolis, yet they also arose within the context of an increasing concern over otic health after mid-century. ${ }^{17}$ Jonathan Sterne has argued that an augmented interest in issues of listening and hearing predates the introduction of recording technologies in the late nineteenth century, remarking that 'the new science of otology or ear medicine constructed diseases of the ear as a

12 Gillmore 1876, 205. ${ }^{13}$ [unsigned] 1883b, 264.

14 Richardson 1882, 241. For an extended discussion of the relationship between insomnia and modernity, see Scrivner 2014.

15 [unsigned] 1897, 12-13.

${ }^{16}$ Fritzsche 2015. See also physician Walter B. Platt's 1888 article 'Injurious Influences of City Life', which identifies 'the incessant noise of a large city' (485) as injurious to residents of various European and American cities (487).

17 It is telling that around mid-century, popular literature about the preservation (and loss) of hearing begins to appear in print in Europe and North America, such as Clark's (1856) practical guide Sight and Hearing: How Preserved, and How Lost, Fowler's public lecture from 1865, 'The Eye and Ear, and How to Preserve Them', and the unsigned 1854 essay 'Das menschliche Ohr'. 
problem separate from the eye'. ${ }^{18}$ Indeed, the discipline had advanced so far in the second half of the nineteenth century that in 1884 the noted Scottish otologist Thomas Barr could remark with pleasure on 'the increased interest in diseases of the ear taken both by the public and the profession, and especially as the result of fuller and more correct knowledge of the serious consequences which may attend them'. ${ }^{19}$

Already in 1822, occupational hearing loss is a topic for the French physician Philippe Patissier, whose Traité des maladies des artisans prominently mentions noise as hazardous for craftsmen: 'The noise that these craftsmen make with their hammers disturbs the neighbours of their studios as well as they themselves. ${ }^{20}$ Still, the medical literature before 1850 tends to reference natural sources of auditory damage, like Jacob Breder Heidenreich's 1850 summary of Kramer's advice for ears: 'You should be careful of factories that produce noise, song birds, loud speech, etc. $^{, 21}$ It stands to reason that the earliest otologists of the century would invoke the sound world around them in describing hazards for human hearing, which generally did not yet encompass noises from boiler shops, trains and streetcars: thus, writing in 1827, the venerable French specialist Jean Antoine Saissy references harmful environmental 'violent noises' like those of thunder, (church) bells and artillery, but not industrial machinery. $^{22}$

If, as Sterne argues, the ear and its diseases had received scholarly attention primarily in the context of the other sensory organs (especially the eye) earlier in the nineteenth century, during the second half of the century study of the ear, its function and dysfunction preoccupied a variety of medical specialists. ${ }^{23}$ It was German-speaking Europe that led

18 Sterne 2003, 51. Otology is the medical study of ear physiology and pathology, while audiology is a health-care discipline that assesses hearing loss and treats it through therapy.

19 Barr 1884, 358-9.

20 'Le bruit que ces artisans font avec leurs marteaux incommode les habitans voisins de leur atelier, et les affecte eux-mêmes.' Patissier 1822, 81.

21 'Man habe Acht gegen Fabriken, die Lärm veranlassen, Singvögel, lautes Sorechen u. s. w.' Heidenreich 1850, 152.

22 Saissy $1827,178$.

23 Sterne nevertheless overstates the case for otology emerging from study of the sensorium, omitting reference to the various medical specialists in Great Britain, France and the United States who were devoting themselves exclusively to pathologies of the ear in the early nineteenth century. Among these texts are Saunders 1806, Itard 1821, Buchanan 1828 and Pappenheim 1840. See Esmail 2013, 41. For a history of otology, see especially Pappas 1996. The comments of American scientist Benjamin Silliman are indicative of the attitude that the eye and ear belonged together: 'the eye and the ear, each in pairs, corresponding to the double brain, are placed close to that intellectual organ, and communicate directly with it; they are the most elevated and dignified of the senses'. Silliman 1840, 80. 
the way in the newly established medical science of otology, with landmark studies about the ear's health and pathology by Wilhelm Kramer (18011876), Anton von Tröltsch (1829-1890) and above all Adam Politzer (1835-1920). ${ }^{24}$ Politzer established the first ear clinic in 1863 at the University of Vienna and subsequently founded with Tröltsch and Hermann Schwartze (1837-1910) the first international journal of otology as the Archiv für Ohrenheilkunde in $1864 .{ }^{25}$ Hermann von Helmholtz's classic text Die Lehre von den Tonempfindungen of 1863 falls squarely within this initial period of heightened European interest in the physiology of the ear, ${ }^{26}$ but only Helmholtz (1821-1894) significantly forges a link with the psychology of hearing and - more importantly - listening. Helmholtz had already drawn that distinction in the noted lecture from 1857, wherein the audiologist distinguishes 'between the material ear of the body and the spiritual ear of the mind'. ${ }^{27}$ Later in the century, Politzer proceeded to publish (in 1878) the first volume of his comprehensive textbook of otology Lehrbuch der Ohrenheilkunde, whose second volume appeared in 1882. At the same time, pioneering research on the ear and its maladies was being carried out in France, England and the United States, ${ }^{28}$ by figures like Prosper Ménière (1799-1862), Joseph Toynbee (1815-1866) and Daniel Bennett St John Roosa (1838-1908). ${ }^{29}$

The texts authored by these otologists and their colleagues feature both general introductions to the field and specialised studies of hearing problems. (Table 7.1 presents a selection of key nineteenth-century texts on the ear and its diseases and injuries.) As aids to students and members of the medical profession, the manuals, handbooks and treatises from the second half of the century treat not only diseases of the ear but what Laurence Turnbull, writing in the Medical and Surgical Reporter of 1865, called 'acoustic injury. ${ }^{30}$ In the general volumes on otology the specialist reader would find diverse chapters on conditions of the ear, systematically leading the reader from basic physiology through common and then

24 Primary publications of these otologists are as follows: Kramer 1867, Tröltsch 1862, and Politzer 1878/82 and 1907/13.

25 On Politzer's accomplishments as an otologist, see Mudry 2000. ${ }^{26}$ Helmholtz 1863.

27 Helmholtz 1883, 88. Helmholtz's research and lectures in Bonn in the mid-1850s already demonstrated this interest in the physiology of the ear: his appointment there was as a professor of physiology and anatomy. See Steege 2012, xi, 40.

${ }^{28}$ It is important to recognise that these scientists working on auditory damage were physiologists, not acousticians, i.e. they were investigating pathologies of the body, which are quite separate from the nature and effects of sound that are the topics of research in acoustics.

29 Their primary texts: Toynbee 1860, Ménière 1861, Roosa $1873 .{ }^{30}$ Turnbull 1865, 88. 
Table 7.1 Key nineteenth-century texts on the ear and its diseases and injuries

\begin{tabular}{ll}
\hline 1806 & John Cunningham Saunders, The Anatomy of the Human Ear \\
1821 & Jean Marc Gaspard Itard, Traité des maladies d'oreille et de l'audition \\
1827 & Jean Antoine Saissy, Essai sur les maladies de l'oreille interne \\
1828 & Thomas Buchanan, Physiological Illustrations of the Organ of Hearing \\
1840 & Samuel Pappenheim, Die specielle Gewebelehre des Gehörorganes \\
1859 & Julius Erhard, Rationelle Otiatrik nach klinischen Beobachtungen \\
1860 & Joseph Toynbee, The Diseases of the Ear: Their Nature, Diagnosis, and \\
& Treatment \\
1861 & Prosper Ménière, 'Mémoire sur des lésions de l'oreille interne' \\
1861 & Wilhelm Kramer, Die Ohrenheilkunde der Gegenwart \\
1862 & Anton von Tröltsch, Die Krankheiten des Ohres, ihre Erkenntniss und \\
& Behandlung: Ein Lehrbuch der Ohrenheilkunde \\
1867 & Wilhelm Kramer, Handbuch der Ohrenheilkunde \\
1870 & Josef Gruber, Lehrbuch der Ohrenheilkunde \\
1873 & Daniel Bennett St John Roosa, A Practical Treatise on the Diseases of the Ear \\
1877 & Charles H. Burnett, The Ear: Its Anatomy, Physiology, and Diseases \\
1878,1882 & Adam Politzer, Lehrbuch der Ohrenheilkunde, 2 vols. \\
1884 & Thomas Barr, Manual of Diseases of the Ear \\
1884 & Ludwig Löwe, Lehrbuch der Ohrenheilkunde \\
1907,1913 & Adam Politzer, Geschichte der Ohrenheilkunde, 2 vols. \\
1908 & Georg Boenninghaus, Lehrbuch der Ohrenheilkunde für Studierende und \\
& Aerzte
\end{tabular}

specialised disorders. ${ }^{31}$ Typically the organisation of the pathological sections works its way inward, from the readily observable conditions of the external ear to the subjective assessment of maladies involving the inner ear, called the 'nervous apparatus' by Toynbee. ${ }^{32}$ These authors may devote a brief section of their texts to damage from sonic sources, usually situating sound injuries both in the eardrum and in the organ of Corti, the former due to concussive pressure, the latter to a wide range of traumatic sounds. However, their opinions differed on the actual neuro-mechanisms affected by the injury, even as other disorders of the inner ear such as Ménière's disease - identified by Prosper Ménière in 1861 - had to await an empirical diagnosis until well into the twentieth century. ${ }^{33}$

The studies devoted exclusively to auditory pathologies still valorise conditions caused by disease, but also consider non-physiological sources. These

\footnotetext{
31 For example, Charles H. Burnett's standard textbook (1877). $\quad{ }^{32}$ Toynbee 1860, 348.

33 Gangadhara Somayaji 2015.
} 
include environmental sources, among which harmful noise represents only one of several factors. Adverse weather conditions and atmospheric dust appear with regularity as environmental hazards to hearing, as well as injuries arising from occupational noises. ${ }^{34}$ Although not stated as such, the fear of the times over the deleterious effects of industrial, commercial and transportation noise in the modern city finds support in these publications that establish the medical foundations for auditory injury through sound.

Even contemporary fiction - that arbiter of cultural temperament carried the discourse surrounding injurious sounds, and perhaps nowhere more clearly than in a short children's tale by Timothy Shay Arthur, in The Children's Hour of 1872. Beating on an old tin pan with two bits of iron, ten-year-old Hartley greatly disturbs his mother, who attributes her strong response to nerves. ${ }^{35}$ After explaining what nerves are, she establishes, "If you had struck me on the head with your fist, you hardly could have hurt me worse ... My nerves are very sensitive" ... "But how can a noise touch your nerves?" asked the boy. "It touches the nerves of hearing, and through these jars all the rest". ${ }^{36}$ Such a medicalised narrative reflects the anxieties behind embodied responses to hearing noise, which characterises equally contemporary reaction to Wagner's music, as we shall observe.

Thus otologist John Roosa's 1883 article 'The Effects of Noise upon Diseased and Healthy Ears' discusses in detail the long-term damaging impacts of environmental sounds, invoking some of the most common urban noises of the era: railway carriages, clattering wagons and, especially, boiler shops. ${ }^{37}$ Already in 1859 Julius Erhard's general text on otology had cited the environmental factor of noise in work in hammer mills and with pieces of artillery as being harmful to hearing, and over two decades later, Politzer would identify the occupations of locksmith, blacksmith, miller and cooper as typifying those that led to hearing loss among their practitioners. ${ }^{38}$

${ }^{34}$ Burnett, for example, names mill hands, carpenters, boilermakers and female domestics as examples of workers who are susceptible to hearing loss through environmental factors. Burnett 1877, 403.

35 One possible reading of the story is that Arthur is depicting the human response to the mechanical noise of the industrialised city.

36 Arthur 1872, 11. The modern term for this phenomenon of heightened sensitivity to sound is 'hyperacusis'. Another story that refers to hyperacusis is the novel The Woman in White by Wilkie Collins (London: Sampson Low, 1860).

37 Roosa 1883. In his A Practical Treatise on the Diseases of the Ear, Roosa sets up a binary between 'musical' and 'unpleasant' sounds, as heard in ongoing repetition: 'the continual recurrence of a kind of sound, that has no musical, but on the contrary, an unpleasant character, must at last cause a hyperæmia of the ultimate nerve-fibres of the cochlea' $(1885,667)$.

38 Erhard 1859, 126-8; Politzer 1883, 190. One year after the English-language edition of Politzer and publication of Roosa's article, Thomas Barr indicated the professions of boilermakers, 
However, Roosa conducted specific, extended testing in boiler shops: 'Boilermakers, and those who become deaf from an exposure to the continuous shock of loud sounds, suffer a lesion of the acoustic nerve. ${ }^{39}$ One of his boilermaker interviewees remarked that 'Those heavy hammers jar every nerve in the body. ${ }^{40}$ The evidence compelled Roosa to conclude that 'the hearing-power of persons working in such a din as that of a boiler-shop invariably becomes impaired'. ${ }^{41}$ This important article appeared in the influential Archives of Otology and was translated and reprinted in 1884 in the Zeitschrift für Ohrenheilkunde, where it was cited by other specialists throughout the decade. ${ }^{42}$ Roosa himself would incorporate its findings into later editions of his 1873 text $A$ Practical Treatise on the Diseases of the Ear. ${ }^{43}$

The physiological approach to audition advocated by such medical authorities works from the assumption that the body represents a quasimechanical apparatus, leaving little space for cognition and the life of the mind. ${ }^{44}$ Their discourses of damaged listening acuity are grounded in materialist attitudes toward medical conditions and diagnoses, which explains why the otological literature they produced pathologises physiological phenomena - damage to the eardrum from concussive sounds, for example - rather than cognitive impairment. ${ }^{45}$ As a result, the late nineteenth century became an era of rapid growth in the understanding of ear structures and their functions and dysfunctions.

The materialist paradigm also explains how musical sounds and environmental noises could be rationalised within a single taxonomy of auditory stimuli, which would lead to the argument that certain instruments and manners of performance could be injurious to the ear. For example, Wilhelm Kramer's Die Ohrenheilkunde der Gegenwart of 1861 provides a more detailed taxonomy of damaging noise sources that includes sounds produced by musical instruments:

riveters and railway engine drivers as exemplifying types of work that could be hazardous to hearing. Barr 1884, 54.

39 Roosa 1883, 108.

40 Roosa 1883, 111. Roosa's introductory comment locates the source of the nerve-jarring effect in the ear: 'Boiler-makers speak in graphic language of the effects of the fin upon their ears.'

${ }^{41}$ Roosa 1883, 118. The injury was so common among workers in such factories that it became known as 'boilermaker's disease' or 'boilermaker's ear'.

42 See, for example, R. 1883; Montgomery 1884, 52; and Baber 1888, 298.

43 The book appeared in seven revised editions through 1892.

${ }^{44}$ Historians of science date this attitude towards the human body back to the Cartesian separation of body and mind, which conceived of it 'using physical, chemical and materialist vocabulary'. Hirjak et al. 2013.

45 For a discussion of medical materialism, see H. Cook 1997. 
If at all possible one should go out of the way to avoid noise in mills, factories with clanging machinery, workshops of metal workers, copper smiths and boilermakers, hammer mills, target practice of the artillery and infantry, the use of firearms in hunting, the proximity of wind instruments and violins of heavily staffed orchestras, screeching parrots and canaries ... ${ }^{46}$

Politzer also writes about 'the action [upon the ear] of loud noises ... while driving in loudly rattling carriages or in a railway train, in noisy factories and workshops, while listening to music loudly instrumented, etc. ${ }^{37}$ Under the sub-category 'Subjective Ear Sensations' of the category 'Subjective Symptoms', Politzer considers the condition Hyperasthesia acoustica ('excessive sensitiveness to noises'), in which 'all sorts of music and loud speaking give rise to an unpleasant and often worrying sensation'. ${ }^{48}$ And in the revised 1896 edition of his manual, Barr observes how 'even in persons who may be very deaf, loud sounds, such as speech through a conversation tube, or a railway whistle, or loud music such as that of a large organ, are sometimes very disagreeable or even painful'. ${ }^{49}$ These physiological medical references to heavily orchestrated or merely loud music and its potentially harmful or painful impact upon the hearing of the individual - however realistic they may be - share a precedent that pre-dates the work of Politzer, Helmholtz and their otologist contemporaries: already in the 1853 Ästhetik des Hässlichen, Karl Rosenkranz complained about the 'tickling of deadened nerves ... [through] colossal instrumentation'. ${ }^{50}$ What unites this family of references is the recognition that musical sound can function as an imminent threat to the well-being of an individual, in the manner of the noises produced by the urban soundscape of the street and workplace. Once again we encounter anxieties over music, and sound in general, whose levels of sound intensity could exceed the thresholds for health and human tolerance.

When these medical specialists cite potential injury or pain from music by virtue of its heavy orchestration or 'loud instrumentation', they are marking the characteristics of volume and timbre that have become confused and conflated in contemporary parlance about sources of otological harm. In the introduction to his 1953 Lexicon of Musical Invective, entitled

${ }^{46}$ My italics. 'Dem Lärm in Mühlen, Fabriken mit klappernden Maschinen, in Werkstätten der Schlosser, der Grob-, Kupier- und Kesselschmiede, in Hammerwerken, bei Schiessübungen der Artillerie und Infanterie, beim Gebrauch der Schiessgewehre auf der Jagd, in der Nähe namentlich mit Blaseinstrumenten und Geigen starkbesetzter Orchester, schreiender Papageien und Kanarienvögel ... geht man möglichst aus dem Wege.' Kramer 1861, 34.

47 Politzer 1883, 203. ${ }^{48}$ Politzer 1883, 341. ${ }^{49}$ Barr 1896, 38.

50 '.... sinnlich verweichlichende Melodien, koloffale Inftrumentirung'. Rosenkranz 1853, 52. 
'Non-Acceptance of the Unfamiliar', Nicholas Slonimsky addresses this problem when he famously quips, 'New music always sounds loud to old ears. Beethoven seemed to make more noise than Mozart; Liszt was noisier than Beethoven; Strauss, noisier than Liszt. ${ }^{51}$ While Slonimsky's equating of loudness with noisiness may be problematic today because the two attributions index different modes of perception (in essence, physiological and cognitive), writers in the nineteenth century regularly blended these sources of aural discomfort. ${ }^{52}$ This should be familiar territory to anyone who has worked with the reviews quoted in Slonimsky or with Wilhelm Tappert's 1877 publication Ein Wagner-Lexikon: Wörterbuch der Unhöflichkeit, the inspiration for Slonimsky. ${ }^{53}$

Academics have tended to read the anti-Wagnerian criticisms collected by Tappert as metaphorical hyperbole, whereby commentators registered disapprobation by situating the unfavourable experience of the music in its auditory reception. ${ }^{54}$ In light of the clinical and popular responses to the harmful audible environment of the metropolis, however, is it possible that Wagner's music evoked embodied materialist representations of that discourse? David Trippett suggests as much when he notes that in such literature 'the body's response to melody is no longer a literary metaphor' ${ }^{55}$ Such visually rich tropes of exaggeration as 'ear splitting' and - in German - 'ear-torturing' (ohrenmarternd) denote more than just colourful feuilletonist polemics: they arose in the context of medical discussions over auditory well-being within the injurious/painful urban soundscape of the time. ${ }^{56}$ Hence it was natural that such comparisons

51 Slonimsky 1953, 18. ${ }^{52}$ See Hugill 2012, 52-3.

53 The full title reads Ein Wagner-Lexikon. Wörterbuch der Unhöflichkeit enthaltend grobe, höhnende, gehässige und verläumderische Ausdrücke welche gegen den Meister Richard Wagner seine Werke und seine Anhänger von den Feinden und Spöttern gebraucht worden sind: zur Gemüths-Ergötzung in müssigen Stunden ('A Wagner Lexicon. Dictionary of Rudeness, Containing Coarse, Mocking, Scathing, and Defamatory Expressions Which Have Been Used by Enemies and Mockers of and against Master Richard Wagner, His Works, and His Followers, for Entertainment in Idle Moments').

54 See for example Dreyfus 2010, 35.55 Trippett 2013, 9.

56 'Ear-splitting' is used in [unsigned] 1883a, 604. André Gill's 1869 caricature of Wagner 'splitting' his auditor's ear with a Nibelungen spike and hammer visualises the metaphor in one of the century's most notorious satirical representations of Wagner. One critic's comments about Wagner approach Gill's caricature more closely in referencing the 'ruptured eardrums' (gesprengte Trommelfelle) of Wagner's audience members (Tappert 1877, 5). The German ohrenmarternd is attributed to a letter by writer Eduard M. Oettinger to Alexandre Dumas from 1860, cited in Tappert 1873, 672. Oettinger follows this auditory neologism with another medicalising compound descriptor, nervennörgelnd, which translates as 'irritating for the nervous system'. Combined, the two terms suggest that the brutal sounds impacted the listener's emotional (nervous) state. 
would be drawn when listeners were confronted by music that performed acoustic excess, over and above that which had been experienced in the concert hall to that point. The music critics were accessing contemporary tropes of sonic harm rendered all too familiar through the sheer volume of contemporary urban noise.

It is no coincidence that such language first appears in musical literature after 1860, even as otological terms like Hörverlust ('loss of hearing'), Gehör-Schaden ('hearing injury') and Gehör störend ('damaged hearing') were establishing themselves in German- and English-language medical discourse. ${ }^{57}$ The more specialised and graphic designations for auditory injury in the German language, such as ohrenzerreissend ('ear rupturing'), arose even later in the century, and that specifically in relation to Wagner's music dramas, in particular, Tristan und Isolde. ${ }^{58}$

Tappert recognised the importance of such language in referencing the audible effects of Wagner; his widely circulated lexicon deserves closer consideration not only as an aggregator for bons mots about Wagner from the daily and musical press of the time, but also as a study of the neologisms and derisive vocabulary that the new music provoked. The Wagner lexicographer includes four ear-related entries in the book's primary alphabet: Ohrenschindend ('ear flaying') and Ohrenzerreissend ('ear rupturing'), and Ohrenschmerz ('ear ache') and its synonym Ohrenzwang. ${ }^{59}$ The adjectives designate injurious actions upon the ear, while the nouns describe a condition of the ear, all of which could have occurred in the otological literature of the time.$^{60}$ Elsewhere in the lexicon he quotes (i) the term ohrenzerfleischend ('ear mangling') in reference to Wagner's operas, (ii) the audience member for Die Walküre who needs a goodly amount of 'cotton in his ears' to avoid long-term damage, and (iii) the 'new' introduction to Tannhäuser as 'murderous noise' (Mordlärm). ${ }^{61}$

57 Vocabulary of this kind can be found throughout such standard texts as Gruber 1870 and Löwe 1884.

58 Tappert $(1877,27)$ attributes ohrenzerreissend to the Berliner Montagszeitung of 1874 with regard to an announced performance of Tristan in Munich. The very first reference to Wagner and hearing loss seems to occur in the notorious oppositional journal Niederrheinische MusikZeitung, in a review by 'C.D.' of the Viennese premiere of Lohengrin from 1858 . The critic cites a colleague as saying, 'The twenty-four keys do not provide a good basis for hearing' ('Die vierundzwanzig Tonarten geben keine Basis für das Gehör ab’) (C.D. 1858, 299).

59 C.D. 1858,290

${ }^{60}$ For example, in an 1878 article about the abuse of locomotive steam whistles, the author uses the descriptor 'ohrenzerreissen' for their shrillness to the ears of listeners ([unsigned] 1878c, 155).

61 '... The critic from the Sporn [Hieronymus Truhn] discovered a sea of ear-mangling music of torment [in Siegfried]' ' ... Ein Meer von ohrenzerfleiscbender Quallenmusik entdeckte der 
If Tappert primarily draws upon commentators' neologisms that were applied to listening to Wagner, other authors invoke the sources for those experiences of his music. This is where his material becomes more directly aligned with the urban soundscape. References to Wagner's use of percussion and brass are not uncommon in the sources, which obliquely connect with the injurious noise of the city, such as this Weimar report from Signale of 1865: 'Earlier [!] the Musicians of the Future made a din in our ears until the full complement of cymbals, tam-tam, triangle, and other such beautiful instruments burst through. ${ }^{62}$ Another allusion to industry and hearing loss is encountered in the study by German psychiatrist Theodor Puschmann (1844-1899), Richard Wagner: Eine psychiatrische Studie, where the author suggests the need for aural fortitude to survive Wagner: 'Your auditory nerves must be as thick as ship's cables if you want to come away unharmed from the noise [of a Wagner opera]. ${ }^{63}$

The humorist Daniel Spitzer more overtly positions the composer's work within the noisy milieu of the city in a 'Wiener Spaziergang' from May 1866, entitled 'Die Prater-Ausstellung': 'Where shall I go now? Shall I really plunge into the turmoil of the steam machinery, which creaks, roars, whistles and screeches as if it were performing an overture by Wagner? ${ }^{34}$ The notorious Wagner opponent, who would publish the letters between the composer and a Viennese 'Putzmacherin' in 1877, satirically attempts to re-auditise Wagner's music through the vocabulary of modern auditory trauma: language that accesses lived sound from the reader's somatic experience of such audible effects within the urban environment of the time. $^{65}$

It is possible to argue that as a feuilletonist, Spitzer would have used such metaphorical constructions naturally as a part of the humorist's toolkit. However, a small body of specialised late nineteenth-century literature that

Kritiker des “Sporn”' (Tappert 1877, 30); 'A garnish of ear plugs for Valkyrie visitors' 'Eine Garnitur Gehör-Wattons für, Walkyren'-Besucher' - Tappert found this passage in the Berliner Montagszeitung of 4 May 1874 and cited it (Tappert 1877, 5); quotation by Ludwig Speidel in the Wiener Fremdenblatt of 1872, cited in Tappert 1877, 25. The reference must have been to the Bacchanale in Act I from the Paris version, which was used in Vienna for the 1872 production.

62 'Früher rasaunten uns die Zukunftsmusiker die Ohren bis zum Zerspringen voll mit Becken, Tamtam, Triangel und dergleichen schönen Instrumenten.' Cited in Tappert 1877, 30.

63 'So dass ... die Gehörnerven so dick wie die Schiffstaue dazu gehören, um aus deratigem Lärm [einer Wagner'schen Oper] unversehrt und heil hervorzugehen.' Puschmann 1872, 30.

64 'Doch wohin jetzt? Soll ich mich wirklich in das Gewühle der Dampfmaschinen dort stürzen, die knarren, dröhnen, pfeifen und kreischen, als wenn sie eine Ouvertüre von Richard Wagner aufführten?' Spitzer 1877, 35-6.

65 Spitzer 1906. 
reports on Wagner from the perspective of medical science exists, and makes precisely the same connection. The authors are otologists, who would have had some familiarity with Wagner's music - or at least with the major Wagner tropes in circulation at the time; as medical specialists, however, their assessments of the physiological effects of the composer's works acquire special validity for the present investigation.

In the sixth edition of his textbook from 1885, otologist Roosa - whose 1884 assessment of harmful noises we encountered above - clearly brings the injurious effects of Wagner into the urban soundscape of his time: 'If Galen had lived in the nineteenth century, and in New York with its uneven pavements, boiler shops, locomotive whistles, elevated railways, and Wagner music, he might have added largely to his category of sounds unpleasant to the ear. ${ }^{66}$ Leopold Damrosch's first Metropolitan Opera season (1884-5) featured Tannhäuser, Lohengrin and Die Walküre in 44 of its 101 performances, which obviously left its impact upon New Yorker Roosa, who would surely have attended at least one performance. ${ }^{67}$ As one of New York's more prominent personalities, the otologist could hardly have escaped what Horowitz describes as the city's 'hunger for Wagner', whatever his own misgivings. Roosa's mild adjective - 'unpleasant' describes the sensation of the assorted urban sounds he itemises, but when equated with such noises as those of boiler shops and locomotive whistles, the harmful material impact of Wagner's music on the ear becomes unmistakable.

At almost the same time, physician and ear specialist Dr Carl von Reichert published a study entitled 'Versuch einer Richard WagnerStudie' in a medical journal from 1884, subsequently releasing it as an offprint. $^{68}$ In it the author speculates about the effects of Wagner's music upon the listening layperson, such as in the following passage: 'It is fully in the nature of the layman that to the extent his relatively inflexible eardrum and his insufficiently developed hearing will continuously and most intensively be shattered by powerful new masses of tones; [he] will tend to interpret this musical noise [of Wagner] as never before heard. ${ }^{69}$ Through the last clause Reichert hoped to explain the negative responses to Wagner, but he was also advancing an argument for the physiological basis for

${ }^{66}$ Roosa 1885, 17. ${ }^{67}$ Horowitz 1994, 76-8. $\quad{ }^{68}$ Reichert 1884a, 1884b.

69 'Es liegt ja so ganz in der Natur des Laien, dass er in demselben Maasse, als sein schwer bewegliches Trommelfell und sein mangelhaft entwickeltes Gehör fortwährend und in der intensivsten Weise erschüttert, von neuen gewaltigen Tonmassen ... gereizt wurde, im selben Maasse dann natürlich auch geneigt ist, diesen musikalischen Lärm als noch nie dagewesen zu interpretiren.' Reichert 1884a, 24. 
hearing Wagner, however problematic its audiological foundations may be. ${ }^{70}$ Moreover, Reichert alludes to the noise of modern life when he connects Wagner's followers with 'crass materialism, the golden-calf cult and the general tendency towards degeneration and machinizing, which is the mark of today'. ${ }^{71}$

The third doctor under consideration does not directly bring Wagner into the noisy cityscape, yet his admonitions on opera and otic health are nevertheless revealing. In his textbook on auditory pathology, Ludwig Löwe refers to the harmfulness of operatic music for one's ears without specifically naming any composer, while two passages from 1884 point to Wagner. Firstly, a fairly straightforward warning: 'The ear patient should not be permitted to attend noisy operatic performances. ${ }^{72}$ The second section of text explains the reason for the cautionary note: '[the other senses] are so occupied at a noisy and sumptuous operatic performance that they are not in a position [to substitute for the ear]. ${ }^{73}$ Löwe is suggesting that the listener would experience sensory overload at an opera like Wagner's, an observation that provides a degree of medical verification for the more fanciful descriptions of the music's material impact given by critics. Löwe's concern with overstimulation serves as further evidence for the contemporary unease over the seemingly unbridled cultural transformation wrought by Wagner's music.

Finally, the infamous Wagner caricature by André Gill from 1869 (see Figure 7.1) warrants consideration in this context, for it visualises the otic assault, the physiological impact of Wagner's music. ${ }^{74}$

Here Wagner is depicted as driving a note-spike into an ear with a Nibelungen hammer, drawing blood from the eardrum. Various authors feature this illustration either on the covers or as illustrative material for their Wagner books, and indeed, Gill's work invites multiple readings and

70 The notion of aural over-stimulation through the experience of Wagner's music is certainly not novel, but the implicit reversal of Slonimsky's terms for new music sounding loud to 'loud' (dense) music sounding new does introduce a cognitive response that takes the critical reactions recorded by Tappert one step further.

71 ،... [in Folge des] crassen Materialismus, des goldenen Kalb-Cultus und des allgemeinen Verflachungs- und Vermaschinirungs-Strebens, welches die Signatur der heutigen Tage ist'. Reichert 1884a, 42.

72 'Dagegen soll man Ohrenleidende zu rauschenden Opernaufführungen nicht zulassen.' Löwe 1884, 300.

73 ، ... werden sie bei einer lärmenden und prunkvollen Opernaufführung so in Anspruch genommen, dass sie hierzu nicht im Stande sind ... ' Löwe 1884, 301.

74 After the Ring des Nibelungen premiere, Gill also drew the caricature 'Le Tétralogue Wagner' for L'Éclipse of 3 September 1876, in which Gill uses the same facial features for Wagner while showing the composer beating a large cooking pan. 


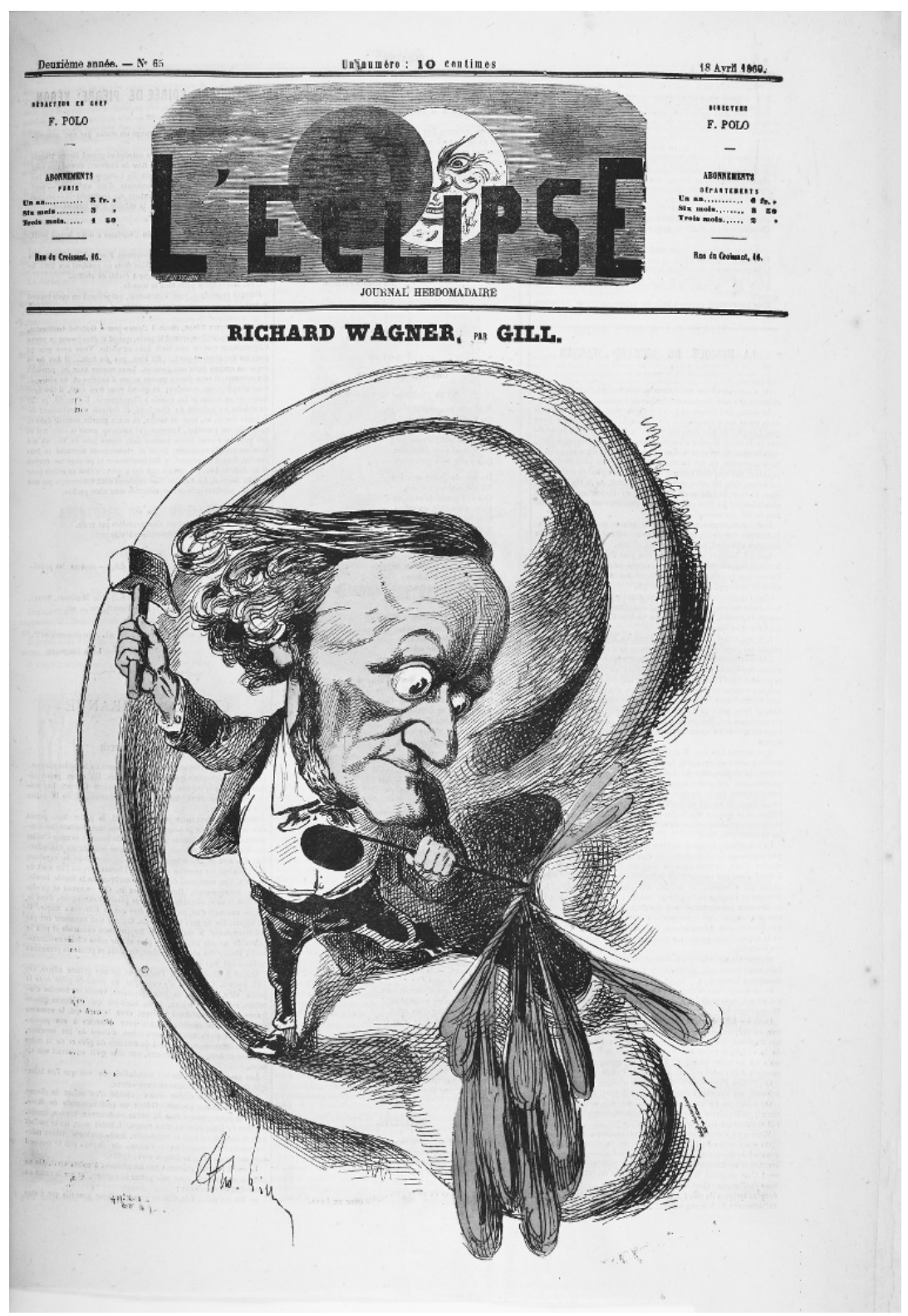

Figure 7.1 André Gill, 'Richard Wagner', L'Éclipse, 18 April 1869 (collection Trippett).

interpretations. Most obviously, the chisel of the Nibelungen is the work tool of the gold-mining dwarves, who were exploited by 'industrialist' Alberich: this exegesis of Wagner's Ring equates Wagner's music with the physical aural harm from the late nineteenth-century industrial 
soundscape. Trippett suggests that Gill's caricature 'captures something of the literalism of this material mode of communication', referring to what he terms 'galvanic' or automatic 'listening', which foregrounds the physiological, sensory economy of the musical experience, something that cannot be resisted by thought and that is grounded in contemporary beliefs in the sensorium's irreducibly material condition. ${ }^{75}$

To sum up this investigation: Wagner's music entered cultural discourse at a time when the medical science of otology was emerging in tandem with issues of ear physiology and hearing pathophysiology. Of particular concern to such medical specialists were the reasons for hearing loss, one cause of which was the noisy urban soundscape of an industrialised modern world. The fears associated with sonic injury would lead to noise abatement societies, literature about the physically and psychically injurious nature of noise and improved ear plugs, but in the late nineteenth century, anxieties over aural thresholds mapped onto the 'loudest' music of the day, that of Wagner. Ear specialists and music critics found common cause in decrying the composer's newly created sound world, mutually shrinking back from what they believed was the limit of material and perceptual endurance for hearing. Of course, in attacking the apparently deafening qualities of Wagner's music, they were not merely warning about dynamic levels, but were conflating a host of musical qualities such as textural density, harmonic complexity and orchestral brilliance, the combined experience of which could well have sounded too 'loud' to contemporary ears, much like the overwhelming noise complex of the modern metropolis.

Wagner's music dramas arrived in a European urban soundscape that rumbled, rattled and roared its way into the ears of citizens, 'straight through their finest thoughts', as Lessing opined. In the same year as Lessing's jeremiad against noise (1908), Breslau audiologist Georg Boenninghaus proclaimed in his Textbook of Otology for Students and Physicians: 'We modern musical human beings no longer sense any discomfort [Unbehagen] over [Wagner's] music; our ear is accustomed to it, and consonance and dissonance are hence not a problem for Helmholtz's theory, but that of psychology. ${ }^{, 76}$ This citation well illustrates the difference a few decades make, from the materialist sensory response to Wagner documented in this chapter to the cognitive, mind-based

\footnotetext{
75 Trippett 2013, 367.

76 'Wir modernen musikalischen Menschen aber empfinden bei dieser Musik [von Wagner] kein Unbehagen mehr, unser Ohr ist daran gewöhnt, und Konsonanz und Dissonanz ist daher nicht Problem der Helmholtzschen Theorie, sondern der Psychologie.' Boenninghaus 1908, 62.
} 
perspective that still prevails today. It also reinforces the historical engagement of medical science with Wagner and his music, a topic that remains under-researched in the literature. And Boenninghaus's remark may well inspire us to ask, where does the threshold of discomfort stand today, and what does that say about listening acuity in our own audible environment? 